\title{
The Scientific Work of the Fishery Board for Scotland.
}

\author{
By
}

\section{T. Wemyss Fulton, M.B.,}

Scientific Secretary, Fishery Board for Scotland.

UP to 1882 the control of the Scottish Fisheries was vested in the Commissioners of British White Herring Fishery. This body, which was instituted in 1808, had for its functions the general superintendence of the herring fishery, the branding of herring barrels, the collection of trade statistics, and the administration of an annual grant from the Government for the construction and repair of fishery harbours. Later on, the cod and ling fisheries were also brought under its care. But the duties of the Commissioners were strictly limited to the fish cured, no cognisance being taken of the fish landed and used in a fresh state.

It was therefore scarcely to be expected that a Fishery Board whose operations were thus circumscribed would concern itself much about the scientific aspects of fishery questions. It is only in recent years that the full value of systematised knowledge concerning such questions has been generally recognised. Occasionally, however, the Commissioners, yielding to the petitions of fishermen or others connected with the industry, instituted inquiries of a scientific character into such points as the distinction between sprats and herrings, the destruction of immature herrings by sprat fishers, or of their spawn by trawlers.

Such investigations were, however, desultory and spasmodic. So soon as the temporary agitation which gave them birth had died away the inquiries lapsed; and from this lack of continuity little of value was accomplished.

In 1882, in response to the growing feeling that the effective management of fisheries should be based upon more extensive and accurate knowledge, and should include every branch and detail of the industry, the old Fishery Board was dissolved, and the present organisation was established in its stead. All the duties of the old Commission were relegated to the new Board, which, in addition, had to take cognisance of the coast and deep sea fisheries, and the salmon fishery; and it was further empowered 
to "take such measures for their improvement as the funds under their administration might admit of." While the traditions of the old Board to some extent survived, and regulated in many ways the operations of its successor, the infusion of new blood, and the presence of one or two scientific men who fully recognised the importance of scientific investigations in connection with the fisheries, led to important departures in the consideration and treatment of fishery questions. It is needless here to defend the value of the application of scientific methods and inquiries in reference to the fisheries; but Professor Cossar Ewart and Sir James GibsonMaitland had to contend with much official inertia and unenlightened obstruction before such methods and inquiries could be made fruitful of results. The lack of funds and of suitable appliances also at the outset hampered the scientific investigations; but means were found to gradually extend their scope as their value became more and more recognised.

A word must be said as to the means at disposal and the methods adopted for carrying on the scientific fishery work of the Scottish Board. The staff of Fishery Officers, gradually formed by the old Board, was utilised as far as possible in the collection of scientific statistics, \&c., and the fishery cruisers were also made use of, so far as their defective qualities allowed, in carrying on the investigations. Temporary laboratories were established for the purpose of prosecuting systematic inquiries; but owing to financial difficulties their utility was somewhat interfered with, and even the use of the large tanks in the Rothesay Aquarium had to be discontinued. At the present time the Marine Laboratory of the Board at St. Andrews is the only one in active operation. As a matter of fact, however, a considerable amount of the scientific work in connection with the Fishery Board has been carried on in the Natural History Department of the University of Edinburgh. Two years ago the Board bought a small steamer (the "Garland"), which has been employed, so far as the annual grant permits, in active investigations into the condition of the fishing grounds, the influence of different modes of fishing in the inshore waters, the habits of the food-fishes, \&c. Hitherto the results of the scientific inquiries have been incorporated with the Report on the commercial aspects of the fisheries, but arrangements have now been made for publishing the scientific portion of the Annual Report separately.

The scientific work of the Board may be grouped under three heads :

(1) Inquiries into general fishery questions, such as the influence of beam trawling, especially in inshore grounds, and of other methods of fishing; the destruction of immature fish; the supplies of bait; 
the collection of special statistics; the survey of fishing grounds, the preservation of fish, \&c.

(2) Biological investigations into the marine Fauna, the structure, distribution, migrations, food, habits, \&c., of the edible fishes, crustacea and molluses.

(3) Physical inquiries into the temperature, salinity, and composition of the waters around the coast.

It is not always easy to draw a line of distinction between the first and second classes, but this division will be enough for practical purposes.

\section{General Fishery Inquiries.}

It would be out of place here to enter into details as to many of the general questions connected with fisheries which have received scientific treatment. One important investigation has been into the influence of beam trawling, especially in the inshore waters. While these inquiries have shown that a great increase of fish, and especially of flat-fish, has occurred in the waters protected from this mode of fishing, they have been the means of throwing light upon the distribution of the edible fishes, their relative abundance at different times of the year, the proportions of immature and adult fish, and other questions of practical and biological interest. These observations were made on board the "Garland" at various parts of the coast. The precise localities and the methods adopted are described in the Report for 1886 ,* the results being discussed more fully in the Report for 1887, $\dagger$ where all the details will be found. From these observations it is evident that by continuing them for a year or two a great deal will be learned of the habits and migrations of the foodfishes. Abstracts of several papers relating to the spawning of fishes will be found below; and a system has been devised by which continuous observations will be made throughout the entire year as to the condition of the reproductive organs and the stomach in different sized specimens of each kind of fish. By this means we shall discover (a) the minimum size of mature individuals of both sexes, $(b)$ the duration of the spawning period, $(c)$ the nature of the food in different seasons, $(d)$ whether there is any variation in the amount of food taken during the period of reproduction, \&c.

The collection of special scientific statistics has been particularly attended to. Besides the Tables of the amounts and values of the different kinds of fish landed, supplied by the Fishery Officers, a scheme has been adopted by having correspondents at the chief

* Fifth Ann. Rep. Fishery Board for Scotland, Appendix F, p. 43, 1887.

† Sixth Ann. Rep., Part iii, p. 25, 1888. 
fishing villages in most districts along the east coast, who furnish details regarding the daily catch, the number of boats fishing, the relative size of the fish, whether got in the inshore or offshore waters, the bait used, the condition of the weather, \&c. Above forty East Coast fishermen have also been supplied with books, and keep records of their daily catches, with particulars as to state of weather and tide, depth, bait, quality and size of of fish, \&c., and by supplying them with charts divided into areas of square miles it will be possible to localise with greater precision the most productive localities. These statistics are given in a large number of Tables,* and have been discussed in last year's Report. $\dagger$

Another point which requires notice is the study of the appliances used in fishing, especially in relation to the capture of immature fish. Experiments are at present being carried on with specially devised trawls with the object of lessening the great destruction of young fish by this mode of fishing. Professor Ewart published a paper last year giving the results of his investigations into the kinds of herring nets used around the Scottish coast, and showing how, by the substitution of light cotton nets for the old hempen ones, and the diminution in the size of the mesh, combined with the earlier commencement of the herring fishing and the greater prevalence of surface fishing, a vastly greater proportion of young herrings are now captured than was previously the case. Other general questions regarding the sprat and herring fisheries are considered in several of the papers referred to below.

The question of bait is one of increasing importance to Scottish fishermen from the growing scarcity of supplies. The common mussel is the chief bait used, and it has been shown that the East Coast line fishermen are put to great expense in order to procure the requisite supplies, and that the total yield of Scotch mussels is rapidly diminishing. The cultivation of mussels is recommended, and experiments have been begun, under the direction of Professor Ewart, with this object in view.

The condition of the shore fisheries is also demanding attention. In a paper in last year's Report $\S$ on the Scottish Lobster Fishery it is shown by Professor Ewart and the writer, that the numbers of this crustacean are rapidly diminishing, and that there is a corresponding reduction in the average size of those taken.

The best modes of preserving fish have been made the subjects of exhaustive investigation by Professor Ewart, but as this is closely

* Fifth Report, p. 82, et seq., 1887.

† Sixth Report, pp. 95-188, 1888.

¥ The Scottish Mussel Fishery. J. C. Ewart. Edin., 1888.

\$ Sixth Report, Part iii, p. 189. 
linked with certain scientific researches referred to below it will be better to consider them together.

The Report for 1885 contains a short paper by Mr. Wilson, the Fishery Officer of the district, on the Fisheries of the Solway Firth;* a similar paper on The Fishing Grounds of the Stonehaven District, by Mr. J. Murray, is given in last year's Report ; $\dagger$ Professor Stirling, of Owens College, has a suggestive paper in the Report for 1885 on Some Economic Products from Fish, $\ddagger$ a subject which deserves far more attention in this country than it has yet received ; and in the Report for $1886 \mathrm{Mr}$. C. E. Fryer, Inspector of Fisheries for England and Wales, furnishes an account of much practical value on The Preparation of Sprats and other Fish as Sardines.§

\section{Biological Investigations.}

One of the earliest questions which engaged the attention of those conducting the scientific investigations was the natural history of the herring. Several papers have appeared in the annual reports on this subject. In that for 1886 there is a long and elaborate memoir by Mr. Duncan Matthews On the Structure of the Herring and other Clupeoids, \| which is illustrated with four plates, and contains the fullest description of the skeleton of the herring which has yet appeared. The skeletons of the shad, the pilchard, and the sprat are also described. It is scarcely possible to give an abstract of this paper, which consists of minute descriptions of every part of the skeleton; but it forms a valuable contribution to the osteology of the Teleostean fishes. In the Reports for 1885 and $1886 \mathrm{Mr}$. Matthews has given the first and second parts of a report dealing with the question of Variety among the Herrings of the Scottish Coasts. These papers embody the results of the examination and measurement of a very large number of herring from both the east and west coasts in winter, spring, and summer, and some idea of the extent and minuteness of this research may be obtained when it is stated that about 16,000 measurements were made. A large number of Tables are included in the report, giving the ratios of the positions of the fins, the relative length of the body and head, the

* Fourth Report, p. 255, 1886.

† Sixth Report, p. 223, 1888.

$\ddagger$ Fourth Report, pp. 256-260, 1886.

§ Fifth Report, pp. 218-221, 1887.

|| Fifth Report, Appendix F, pp. 257-292, pls. xv-xviii, 1887.

ๆ Fourth Report, Append. F, pp. 61-98, 1886; Fifth Report, Append. F, pp. 295316,1887 . 
number of fin-rays, \&c. The general conclusions of the author are : (1) That there is no true racial distinction between the herrings at different parts of the Scottish coasts; (2) That the only difference in favour of a distinction between the summer and winter herring consists in the more posterior position of the dorsal, pelvic, and anal fins, the doubtfully smaller head, and the slightly lesser size of the summer herring; but although this holds for the majority of each season, all the extremes of every variation are repeated among the herrings of both seasons.

In the Report for $1883 \mathrm{Mr}$. Matthews gives the results of his investigations into the Difference between Herrings and Sprats.* Considerable differences existed among the specimens of each species examined. Various external differences are described, such as the general shape and curve of the body, the position of the operculum and suboperculum, the length of the jaw, \&c. These variations are, however, slight and not always easily detected. The best distinctions are the position of the fins and the presence or absence of ventral serration. The scales of the ventral margin have the posterior termination of the median keeled portion sharp and projecting in the sprat, and scarcely developed in the herring. The number of these scales also differs in the young herring and sprat, as does also the number of the scales of the lateral line (fifty-six to fifty-eight in herring and forty-eight in sprat) and the transverse scales (sixteen and eleven or twelve respectively). In the sprat the pelvic fin is anterior to the first ray of the dorsal, but posterior in the young herring. The variations in the position of the other fins is considerable but inconstant; and the number of rays in the fins varies, except in the pelvic, which has seven in the sprat and nine in the herring. Mr. Matthews states that the distinction based upon the presence of vomerine teeth in the herring and their absence in the sprat is difficult to determine in practice. The chief internal or structural differences are: (1) forty-eight vertebræ in the sprat and fifty-six in the herring; (2) a less number of gill rakers and branchial filaments in the sprat; (3) seven or eight pyloric cæca in the sprat, and eighteen to twenty-four in the herring, and they are differently arranged; (4) in the herring each of the two anterior ducts passing forwards from the swim bladder to the head becomes spindle-shaped and bifurcates, each tubular bifurcation terminating at the ear in a spherical capsule, but in the sprat the spindle-shaped dilatation and subsequent bifurcation are absent. Thus there are four anterior spherical capsules in the herring and only two in the sprat. The most certain distinction, of course, is the presence of ripe milt or roe in the sprat. In winter the reproductive organs in young herrings

* Second Report, Append. F, pp. 48-60, pl. iii, 1884. 
and sprats could not be differentiated, but about March in many sprats they were larger, and in June the sprats were nearly all "full" and ripe, while the specimens identified on the above characters as young herring showed no signs of increasing maturity, even when eight inches long. The spawning of the sprat thus occurs in May and June on the east coast of Scotland.* The largest sprat obtained by Mr. Matthews was six inches, the smallest one and three quarter inches, the average size being four to four and a half inches.

The intermixture of sprats with shoals of young herrings, and the great destruction of the latter by sprat fishers, are then discussed. The proportion of young herrings varied from 3 to 80 per cent. In the winter sprat fishing of 1883 along the east coast of Scotland close upon $150,000,000$ young herrings were taken by sprat fishers, 98 per cent. of the total being used as manure.

I may here refer to a paper in the Fourth Report, On the Nature of Thames and Forth Whitebait, by Professor Cossar Ewart and Mr. Duncan Matthews. $†$ The question whether "whitebait" forms a distinct species of Clupea has been often discussed. The authors, after referring to the diverse views held on this subject at various times, give the results of an examination of several thousand specimens of whitebait. Of about 6000 from the Thames, procured in monthly samples between February and August, almost every individual was either a young herring or a young sprat. The percentage of sprats varied from 95 in March to 13 in June. In the Forth the percentage of sprats was 99.5 in the winter. In both the Thames and Forth samples less than 1 per cent. consisted of other small fish, such as gobies and sand launces. In the Report for 1882 Professor Ewart published a paper on the Natural History of the Herring, $\ddagger$ dealing with the supposed existence of varieties, the migrations, the character of the spawning ground, and the spawning process, and describing the artificial fertilization and hatching of herring ova. In regard to the first point it is shown that there is as much difference between specimens caught at the same time and place, as between the spring and autumn varieties of the Baltic herring, established by Heincke. The migrations of the herring and the causes most likely to influence them are discussed. The most important part of the paper deals with the spawning of the herring. The famous spawning grounds at Ballan-

* This agrees with the observations of Dr. Hensen, of the Kiel Commission, who has also shown that the herring and sprat differ markedly in the mode of depositing their ova. In the sprat the eggs are translucent, dispersed and buoyant, floating freely in the water. (Vide Fünfter Bericht der Kommis. z. wissenschaft. Untersuchung d. deutschen Meere, p. 40,1887 .)

+ Fourth Report, Append. F, pp. 98-100, 1886.

¥ Second Report, Appendix F, pp. 61-72, pls. iv-ix, 1884 .

VOL. II, NO. I. 
cods and embryo molluses were rare, larval Decapods frequent, and Sagitta was abundant on the east coast in winter. At certain times and places the food consists largely of sprats or of the ova or young of the herring. On the north-east coast sand-eels form a fair proportion of the herring's food.

The food of the haddock was found to consist chiefly of Echinoderms, especially the common brittle-star (Ophiothrix pentaphyllum), but Asteridea were very rare. Crustacea came next, principally Anomura (Pagurus, Galathea), but also Brachyura (particularly Hyas coarctatus), Macrura and Amphipoda. Only one species of Cumacea and one of Isopoda were obtained. Twenty-one species of Mollusca were identified, almost all being young. Annelids were well represented, especially Aphrodite and others of the Errantia group, and Hydrozoa occasionally occurred. In eight stomachs of the ninety examined, fish remains were found, and herring ova in four, three being full of them.

About 300 stomachs of cod were examined, almost all from the east coast, and representing a period from January to June inclusive. These investigations demonstrate the great voracity and gastronomic impartiality of this fish. In one part of a sea-fowl was found, in another the whole of a lark. In 247 stomachs the remains of fish were found, chiefly haddock, young flat-fish (mostly flounders), herring, and whiting; in 184 there were Crustacea, almost exclusively Decapods, especially Hyas coarctatus, Pagurus Bernhardus, and Crangon Allmanni; in sixty-seven Annelids were present (Aphrodite); in forty molluses, of which ten species, including Eledone cirrosa, were identified. From thirty stomachs the remains of Echinoderms were obtained, the brittle star, as in the haddock, forming the greater proportion, but no Asteroids occurred. The general conclusions in regard to the food of the cod are thus stated: (1) The cod feeds chiefly and constantly on Crustacea, Gadidæ, and Pleuronectidæ; (2) Aphrodite forms an important part of the food in the spring and summer in districts where this form is plentiful; (3) in the winter the cod is attracted to our shores by the large shoals of herring seeking their spawning ground, and at this time herring and herring ova form the staple food material ; (4) Echinoderms and Mollusca do not contribute an important part of the food supply ; (5) the cod feeds much more on fish and much less on Echinoderms than is the case with its ally the haddock.

Of the whiting, 400 stomachs were examined, obtained mostly during autumn and winter, and from the east coast. The food of the whiting is almost limited to small fish and Crustacea; no Echinoderms were found, and of molluscs only a few fragments of the common mussel, probably nibbled from the hooks of line fishermen. 
The Crustacea (found in 53 per cent. of the stomachs) were almost wholly confined to shrimps and prawns, but they were not quite so abundant as the small fish (in 57 per cent.), chiefly young cod and haddocks and sprats. The above papers contain a large number of Tables giving full details.

The food of young cod and saith (which were found frequenting the Zostera-beds in Loch Fyne in enormous numbers) was investigated. In the case of the young cods-measuring from one and a quarter to three inches in length-the smaller specimens contained almost nothing but Copepods, and the larger ones also Amphipods, Mysidæ and Isopods. The stomachs of the young saith (two and a half to five inches long) contained Copepods, Sagittr, young Gasteropods, Amphipods, Schizopods, and Isopods.

In the Report for 1884 there is a paper by Professor Ewart and Mr. Brook on the Spawning of the Cod* in which an account is given of the natural process as observed in the tanks at the Rothesay Aquarium, and of experiments which were conducted in artificial fertilization. It appears that the process of spawning occurs chiefly at dusk and in the early morning, the spawn being shed while the fish are freely swimming about, and fertilized as they rise towards the surface.

Tables giving the Spawning Period of the British Food-fishes, compiled by Mr. Brook from various sources, will be found in the Report for 1885 ; $\dagger$ and an account of the Spawning of the Pike. by the same author, in the Report for 1886 .

The Artificial Hatching and Rearing of Sea-fish, is dealt with by Professor Ewart in a paper in the Report for 1886. $\S$ The fundamental problems connected with this subject are discussed in the light of the knowledge acquired by the culture of the Salmonidæ, and the operations which have been carried on in the United States, Norway, and Germany, in the cultivation of edible fish. Various apparatus for the hatching and rearing processes are described and figured; and it is pointed out that by systematic hatching and rearing of marine forms, such as the more important flat-fishes, lobsters, \&c., a great deal might be done to recruit the inshore fisheries. Professor Ewart also contributed a Report on the Progress of Fish Culture in America to the Report for 1884, $\|$ which contains a full account, based upon personal observation, of the methods adopted in the United States and of the results accomplished up to 1884.

* Third Report, pp. 52-55, 1885.

† Fourth Report, pp. 242-254, 1886.

$\ddagger$ Fifth Report, pp. 347-349, 1887.

$\S$ Op. cit., pp. 230-244, pls. vii-x, 1887.

|| Third Report, pp. 78-91, 1885. 
In the Report for 1883 , Professor Stirling gives a paper on the Chemistry and Histology of the Digestive Organs of Fishes,* which contains an account of the digestive processes in the herring, cod, haddock, and skate, and of the histology of the alimentary tract of the herring. The reactions of the various parts of the digestive canal were found to agree with those in mammals. In the herring peptic extracts were obtained from the stomach; a stronger one from the crop or "cardiac sac," and a weaker one from the gizzardlike "pyloric sac." The pyloric appendages yielded a tryptic ferment, $i . e$. were pancreatic in function, and they probably also secrete a diastatic ferment. The bile was neutral or faintly alkaline and contained a diastatic ferment. In the cod and haddock the gastric extract was purely peptic; trypsin was present in the pyloric appendages, and the bile contained a diastatic ferment. In the skate also pepsin was demonstrated in the stomach, a diastatic ferment in the bile, and glycogen and sugar in the liver. The histology of certain portions of the digestive tract in the herring is fully described.

The results of an elaborate research by Professor Ewart into the phenomena of rigor mortis in fish, and its relation to putrefaction, $\dagger$ and of another on the presence of bacteria in living fish, $\ddagger$ have been recently published. In the former the gradual onset of rigor, the conditions which accelerate or retard it, and its relation to the subsequent processes of putrefaction, are set forth in detail, and a large number of experiments are described. In the latter the occurrence of bacteria in the blood and tissues of living fresh-water and marine fish is described; the causes and results of their presence being considered. In a third paper, $\S$ Professor Ewart goes fully into the practical consequences of these researches, and gives the results of his researches into the action of various reagents and processes in the preservation of fish, together with many details and suggestions as to the best mode of applying them in practice.

Professor Stirling, in the Report for 1885, furnishes a paper on the Red and Pale Muscles in Fishes.\| After summarising our knowledge concerning the dark and pale muscles in animals belonging to various groups, and referring to the anatomical disposition of the muscles in an osseous fish, the arrangement and microscopical appearance of the red and pale muscles in the herring, whiting, mackerel, haddock, and plaice are described.

Dr. W. D. Halliburton, in the same Report, gives the results

* Second Report, pp. 31-46, pls. i, ii, 1884.

† Proc. Roy. Soc., vol. xliii, p. 438, 1887.

‡ Proc. Roy. Soc. Edin., 1887.

$\S$ The Preservation of Fish, London, 1887.

|| Fourth Report, pp. 166-170, pls. iii-v, 1886. 
of an investigation on The Blood of Nephrops norvegicus.* The appearance and properties of the blood when shed, the process of coagulation, the composition, the proteids of the plasma and serum, and the nature of the colouring matters are described in detail.

In the Reports for 1885 and 1886, Mr. John Wilson furnishes an account of his studies on The Development of the Common Mussel. $\dagger$ The reproductive organs, spermatozoa, and ova are described; the method adopted for artificial fertilization explained; and, especially in the second paper, a full account of the development of the embryo, so far as observed, is given.

In a series of papers read before the Royal Society, Professor Ewart has given the results of his investigations into the structure and development of the curious electric organs in the skate.

The first $\ddagger$ deals especially with the development of the organ in the common skate, each step in the process of the conversion of simple muscular fibres into the highly complex electric dises having been followed. The development of the dises is very fully explained. In a second paper§ the electric organ of Raia circularis is fully described and compared with the corresponding organ in other species. In another paper\|the structure and development of the electric organ in Raia radiata are explained in detail and compared with the organs in $R$. batis and $R$. circularis, and the author shows that the less complex structure of the organ in $R$. radiata must be looked upon as evidence that it is in a state of progressive development rather than in a stage of degeneration.

Mr. R. D. Clarkson contributes a paper to the Report for 1886 , On the Nutritive Value and Digestibility of Fresh Fish, $\boldsymbol{\Phi}$ which contains a review of what has been done on this subject, the labours of Atwater, Chittenden, and others being discussed. It would appear, from the variation in the methods employed by different investigators and the diversity of the results obtained, that there is much yet to be done on this subject.

Scattered throughout the Annual Reports are several papers dealing with the marine Fuuna of special localities.

Mr. W. L. Calderwood has given a list of the Copepoda obtained in Loch Fyne, with brief descriptions of each species.** Twentyeight species were collected by the tow-net, ten belonging to the

* Op. cit., pp. $171-176,1886$.

† Op. cit., pp. 218-222, 1886 ; Fifth Report, pp. 247-255, pls. xii-xiv, 1887.

$\ddagger$ Phil. Trans., vol., 179, p. 399, 1888.

$\S$ Op. cit., p. 410.

\| Phil. Trans., vol. 179, p. 539.

वा Fifth Report, pp. 221-229, 1887.

** Fourth Report, pp. 147-154, 1886. 
Calanidæ, fifteen to the Harpacticidæ, two to the Artotrogidæ, and one to the Cyclopidæ. The list has been since extended.

In the same report the Rev. Canon Norman supplies descriptions of A Crangon, some Schizopoda, and Cumacea new to, or rare in, the British Seas.* A new species of Schizopod (Siriella Brooki) from Loch Fyne is described. Species here first recorded as British are : Crangon (Cheraphilus) neglectus, G. O. Sars; Erythrops pygmæa, G. O. Sars; Mysidopsis gibbosa, G. O. Sars; Leptomysis lingvura, G. O. Sars; Siriella Clausii, G. O. Sars ; Lamprops fasciata, G. O. Sars; Diastylis rugosa, G. O. Sars; Pseudocuma cercaria (van Beneden). All were obtained in Loch Fyne.

Also, in the Fourth Report, there is a List of the Marine Fauna collected at the Tarbert Laboratory (Loch Fyne) during 1885 , $\dagger$ by Mr. Brook and Mr. Scott. This list includes fifty-seven species of fishes, 147 species of Mollusca, 127 species of Crustacea (exclusive of Amphipods), twenty-three species of Echinoderms (exclusive of Holothurians), and forty species of Foraminifera. Those which are known to furnish food to fishes are specially indicated.

Dr. Brady, in the Report for 1886, supplies Notes on Entomostraca. $\neq$ A list of fifteen Ostracoda is given, including a new variety (Cypris virens, var. monilifera, nov.) and a form (Cypris Browniana, Jones) previously known only in the fossil condition. In describing the occurrence of Peltidium purpureum, Philippi, for the first time in British seas, Dr. Brady points out that this species is not synonymous with Peltidium depressum, Baird (as it was doubtfully made in his classical Monograph on the British Copepoda), but that the two species are separated by characters of generic importance. Hence the three species referred to Peltidium in the monograph must henceforth take Baird's generic name, Alteutha. A full definition of the genus Peltidium is given.

In the Report for 1887, Dr. Brady gives a description and figures of a new Copepod, Cyclops Ewarti; $\S$ and $\mathrm{Mr}$. Thomas Scott of another, Artotrogus papillatus.\| Mr. Scott also furnishes a List of the Crustacea of the Firth of Forth, 9 by far the fullest yet published, several species new to Britain being described.

Mr. W. L. Calderwood, in the Report for 1885,** contributes Notes on the Greenland Shark (Lœmargus microcephalus), em-

* Op. cit., pp. 155-166.

+ Op. cit., pp. 231-242.

‡ Fifth Report, pp. 328-330, pl. xix, 1887.

$\S$ Sixth Report, p. 232, pl. viii, 1888.

|| Op. cit., p. 232, pl. viii.

T Op. cit., p. 235.

** Fourth Report, pp. 228-231, pl. x, 1886. 
bodying the results of his dissections of two specimens. The same gentleman, in last year's Report, furnishes Notes on an Intra-uterine Specimen of the Porbeagle.*

A Note on the Ova, Fry, and Nest of the Ballan Wrasse (Labrus maculatus), by Mr. Duncan Matthews, appeared in the Report for 1886. $\dagger$ The very curious nests of this species, the ova, and the appearance and remarkable habits of the embryo, are carefully described.

Descriptions of new or rare fishes, which have been obtained by the Fishery Officers or otherwise, have been given from time to time. Thus a new British blenny (Lumpenus lamprœtiformis) has been described and figured by Dr. Francis Day; $\ddagger$ and Torpedo nobiliana, Rhombus maximus, and Lampris luna have been described, and the two first figured by Professor Ewart. $\S$ Among the rarer fishes obtained may be mentioned Carelophus ascanii (Walb.); Ctenolabrus rupestris, L. ; Centrolabrus exoletus, L. ; Motella cimbria, L. ; Zeugopterus unimaculatus (Risso)-which is figured-Pristiurus melanostomus (Raf.), \&c.\| Mr. Brook gives an account of the remarkable chromatic changes in the Dragonet (Callionymus lyra). .

Several papers have appeared in the Reports dealing with pathological conditions in fish, and with the presence of micro-organisms in river-water.

Dr. Barret gives A Note on the Liver of a Haddock, in which a Sand-eel was partly Embedded,** describing the naked-eye and microscopic appearances; and Dr. Woodhead gives an account of Caseous Tumours found in the Muscles of the Hake.††

There are three papers by Professor Greenfield (who was assisted in this research by Dr. Griffiths, Dr. Woodhead, and Dr. J. Gibson), On the Examination of River-Waters for Micro-organisms. $\ddagger$ The object of this investigation was to discover and describe the various forms of minute fungi, and especially bacteria, which are present in river water, and which form an important factor in its impurity in relation to fish life. Specimens of water from important salmon rivers such as the Tweed, the Dee, and the Tay, were examined. Full details are given as to the methods adopted in

* Sixth Report, Part iii, p. 263, 1888.

† Fifth Report, pp. 244-247, pl. xi, 1887.

$\ddagger$ Second Report, p. 78, pl, x, 1884.

$\S$ Op. cit., pp. 79, 80, pls. xi-xiii.

II Fourth Report, pp. 222-227, pl. ix, 1886.

T Third Report, p. 68, 1885.

** Op. cit., p. 70, with three plates.

†† Op. cit., p. 76 .

¥ Op. cit., pp. 73-76; Fourth Report, pp. 176-188, 1886; Fifth Report, pp. 331$347,1887$. 
obtaining the samples and in carrying on the research, and a large number of micro-organisms are described.

The results of a bacteriological investigation of "red" cod, by Dr. Alexander Edington, are given in the Report for this year,* and a Note on the Nature of Red Cod, by Professor Ewart. $\dagger$

In each Annual Report Prof. McIntosh has supplied a number of brief but interesting notes dealing with a great variety of topics concerning marine life, such as the ova, development, and young of fishes, the diseases of fishes, new or rare forms, \&c. These notes are, as a rule, so brief and numerous that it is not possible to make an abstract of them. In this year's Report Prof. McIntosh refers to the use of Annelids as bait, and shows how pressing the question of bait is becoming.

\section{Physical Investigations.}

The investigation of the physical conditions of the sea forms an important part of the scientific work connected with fisheries. It is not, however, always easy to carry on such inquiries as thoroughly as might be desired, for it is a matter of great importance that they should be continuous, and conducted at as many points as possible. The measures adopted by the Fishery Board have consisted (1) in utilising as far as possible the fishery cruisers in the service of the Board ; (2) in instituting special cruises to investigate the physical conditions of particular areas ; (3) in carrying on series of observations on board the "Garland" during the trawling experiments. The data supplied from the first source have not as yet been published, owing chiefly to want of space for the extensive Tables; the "Garland's" observations have been given in the Tables in connection with the trawling reports, and the investigations into particular areas are referred to below. The system of physical inquiries is now in process of reorganisation, and it is to be hoped that it may be found possible to carry on continuous observations at several parts of the Scottish coast. Arrangements have been completed with the Northern Lighthouse Board by which daily observations on the temperature and density of the sea will be recorded by the officers on board the lightships and at the various lighthouse stations in the area embracing the estuary of the Tay, St. Andrew's Bay, and the Firth of Forth. Since this area includes that in which the principal biological investigations are going on,

* Sixth Report, p. 207, pls. vi, vii, 1888.

† Op. cit., p. 204. 
and is from its conformation and the position of the observing stations singularly well adapted for obtaining data to bring the phenomena of atmospheric meteorology and marine physics into relationship with those of marine life, these observations will furnish very valuable results.

In 1883 special physical work was carried on by Dr. Gibson during a cruise of the "Jackal" in the Moray Firth. The methods and results are given in the Report for $1883, *$ the paper being illustrated by a chart; several Tables showing the temperature, the density, and the ratio of total halogen to density at different depths at the various stations. In 1886, during a cruise of the "Garland" in the Moray Firth, physical observations were made by Dr. Gibson and Dr. H. R. Mill, who has done so much in the study of marine temperature. The results of these investigations are embodied in two papers in last year's Report, $\dagger$ which are illustrated by four plates and furnished with many Tables. In the same Report there is a paper by Drs. Mill and Gibson describing the apparatus required for marine physical observations ; $\ddagger$ and another by Dr. Mill (illustrated by a chart and two plates) dealing with the physical conditions of the sea to the west of Lewis.

To the Report for 1886 Dr. Mill contributed a paper On the Physical Condition of the Firth of Forth, $\$$ which is accompanied by a Table giving the density, salinity, and alkalinity of the water, three plates showing the curves of salinity and temperature, and a large bathymetrical chart.

During September last H.M.S. "Jackal" was engaged in a cruise of physical investigations, under the charge of Dr. Gibson, along the east coast of Scotland, and across the North Sea to Bergen and Copenhagen. A large number of stations were formed, at which vertical series of temperature, density, and alkalinity observations were made, the gaseous constituents determined, and samples of water collected for analysis.

* Fourth Report, pp. 189-201, pls. vi, vii, 1886.

† Sixth Report, Part iii, pp. 313-347, pls. xi-xiv, 1888.

$\ddagger$ Op. cit., pp. 309-312, pls. ix, x.

$\S$ Fifth Report, pp. $349-354$, pls. $x x-x x i i i, 1887$. 